\title{
Environmental Rights for Administering Clean and Healthy Environment towards Sustainable Development in Malaysia: A Case Study
}

\author{
Noor Mohammad ${ }^{1}$ \\ ${ }^{1}$ Faculty of Law, Universiti Kebangsaan Malaysia (UKM), Malaysia \\ Correspondence: Noor Mohammad, Faculty of Law, Universiti Kebangsaan Malaysia (UKM), Bangi 43600, \\ Malaysia. Tel: 603-89216354. E-mail: noormmu2011@gmail.com
}

Received: April 7, 2014

Accepted: June 4, 2014

Online Published: July 25, 2014

doi:10.5539/ijbm.v9n8p191

URL: http://dx.doi.org/10.5539/ijbm.v9n8p191

\begin{abstract}
Malaysia is one of the environmentally rich and developing countries in the globe which is in fact, very attractive and charming to all. But her bounty has been degrading gradually due to environmental pollution and therefore, the people's rights are not maintained \& ensured properly as guaranteed by their constitution which is also part of the environmental rights in the light of the international environmental laws. Meanwhile, the Government of Malaysia passed some important environmental laws including 'the Environmental Quality Act 1974; the Environmental Quality Regulations 1989 and the Environmental Quality Order 1989 etc; along with the international environmental laws in order to keep the clean and healthy environment but not yet been properly done in compliance with the above laws. Consequently, sustainability may not be made possible. It may also affect the biodiversities in flora and fauna. Moreover, it is observed that the existing legal mechanisms are not friendly with the environment and development due to absence of environmental governance including the insufficient environmental provisions, inadequate penal provisions, lack of political commitment, lack of resources, unawareness, short term planning etc.
\end{abstract}

Keywords: environmental rights, clean and healthy, environment \& sustainability

\section{Introduction}

The term 'environmental rights' is a very vague and vast issue related to the concept of the environment. The Environmental Science Dictionary defined the environmental rights as a right enjoyed by all members of society that people can live and work in a healthy, safe and comfortable environment. It also states that it includes the right of life and healthy, the right of property security and the right of comfortable environment for living and working. The Environmental rights mean access to the unspoiled natural resources that enable survival, including land, shelter, food, water and air. They also include more purely ecological rights. In Friends of the Earth's includes the political rights as mentioned in the International Covenant on the Economic, Social and Political Rights 1966 and of course the International Covenant on the Civil and political Rights 1966. It is in fact a new idea in the history of legal systems of the world. Its concept may be identified in the different religions. But we hardly forget the role of different religions relating to a clean and healthy environment. There are many messages in this regard. It may be treated as the religious based rights. This idea is discovered in 1960s. In the late 20th century, it observed that the environmental problems were acute that affects the economy. Consequently, the environmental rights began to grow fast. In 1970s, it is found that the European Commission of Human Rights accepted the theme of environmental rights and recognized it as human rights. With this inclusion, the human rights have been increasing and developing at home and abroad. There are many constraints towards the human rights and the environmental rights as well. The current pollution and damages of environment and lack of natural resources have been threatening the survival of human beings with an unprecedented degree. It needs to have the immediate solution for the freedom of the mankind for the purposes of making a beautiful world for our generations. It is a harmonious development based rights that promotes the sustainable development. It has become a fundamental part of environmental law. It safeguards and facilitates the human rights. It is hoped that the world leaders will work for the interest of the mankind irrespective of race, religion, colors, language, sex etc. The Environmental rights are the new human rights that everyone is born with and area also natural rights that cannot be deprived. It is treated as the 'should have rights' not as the practical or 
statutory rights. It drives to produce the better conditions of life on the earth. The environmental rights need time to its development. It needs immediately for legalization and institutionalization. In fact, an idea of environmental rights relating to the harmonious development between the human beings and nature confirms to the natural rules and the trend of development. We can create a better environment for the people to live and protect the interest of both current and future generations by obeying the natural rules and establishing the harmonious development simultaneously. We should not forget the WHO declaration made more than six decades ago that "enjoyment of the highest attainable standard of health is one of the fundamental rights of every human being". The ancient people were very much obeyed with the nature and the natural law. The environmental rights is also considered and based on the anthropocentrism and eco-centrism. In the global context, it is found many international environmental initiatives have been made to ensure the environment al rights and protection. The Aarhus Convention is the best that deals with the environmental procedural rights such as the access to information, public participation and access to justice that may one of the ways and means with a realistic way for attaining the sustainable development. The state party should enact laws to ensure rights to the people of the land. Some important steps were taken for creating awareness on environmental matters after the Stockholm and Rio Declaration. In the regional level, it is found that there some organizations such as the Association of South East Asian Nations, (ASEAN), the South Asian Association for Regional Co-operation (SAARC) etc., have been made for conserving and developing their own environment and therefore, all initiatives are incorporated in their charters. It has some objectives and purposes that may denote the environmental rights to each other.

\section{Meaning of the Environment}

In order to understand the environmental rights, we need to understand the meaning of the environment. A few of the definitions are given below. The Environmental law ensures the environmental rights. Its functions depend on the environment. Its normal meaning relates to surrounding's but obviously it is a concept that is relative to whatever object it is which is surrounded. It is originated from the French word "environ" which means encircle or make surroundings. Finally, it may be said that the environment covers everything on this earth.

\section{Definition of the Key Terms}

There are three key terms in this work such as (a) the Environmental Rights, b) the Clean and Healthy Environment and c) the Sustainability.

\subsection{The Environmental Rights}

Generally, the environmental rights defined as a bundle of rights relating to the environment and development. The environmental right includes the rights of every being on the earth. It defines in the legal foundations. It is in fact the procedural and universal rights applicable to all beings including the flora and fauna. It may include all human rights. The maintenance of those rights reflects the environmental justice. It keeps the ecology free from destruction and maintains every being's rights. It ensures the rights and duties including the responsibilities balance with the nature. It prevents from harmful activities to the nature. Without maintaining the environmental justice, the environmental rights will be meaningless. These rights are recognized and protected by the international environmental laws which should be realized for the beings on the earth. As pointed out by Birnie and Boyle that it promotes environmental justice and all initiatives are made for the protection of the environment and development. The Aarhus Convention 1998 is notable which has been securing citizen's rights through access to information, public participation and access to justice for a healthy environment. The access to information is treated as the heart of the sound environmental protection and sustainable development. The public participation is the heart of democracy and the government is informed about their role in the country. The access to justice enables people to assist the Government to enforce the laws for ensuring environment rights. It gives all information and status of the legal mechanisms based on the scientific studies. Therefore, the concerned authorities including the civil society and other stakeholders may be aware about their duties and responsibilities. It helps to the people for environmental decision making.

\subsection{The Clean and Healthy Environment}

There are two words here such as the 'clean' and the 'healthy' environment which is very closely connected and interlinked. It is very difficult to explain these two terms. With the beginning, it may be stated that a clean Environment is a Human Rights. However, health is a state of complete physical, mental and social well being and not merely the absence of disease or infirmity. The scope for creating a healthy environment is clearly not limited to hospitals and doctor's surgeries, but includes the myriad factors that influence to health, agriculture and food, education, housing, employment status and working environment, water and sanitation, and health care services etc. It can communicate with and support each other within our societies. It keeps the environment free 
from threats and crimes. It also keeps the environment free from the pollution. Moreover, it needs to implement the environmental ethics including the morals with the religious guidelines for making the environment clean and healthy. On the other hand, the clean environment indicates free from dirty, noise, sound pollution, restrictions, pollution, garbage, insanitary toilets, and improper disposal of animal waste, improper solid waste management systems. Its importance is discussed in the different religions. The Holy Quran reads that clean and tidy environment is the half part of Iman (believe in Allah) which is very important for our daily life and herein after. In fact, clean and healthy environment leads to the sustainable environment. Lastly, the clean and healthy environment must free from pollution as defined in the Act."

\subsection{The Sustainability}

This topic is very importantly applicable to the environmental governance. It is said that 'sustainability like the democracy is mere ideal towards which we strive, a journey more than a destination, a goal removed from politics. It is an ideal for the generation to generation. This concept is based on commonly accepted principles such as freedom, equity, justice, transparency, accountability like the concept of the good governance. It interlinks with the rights and duties. The sustainable governance is a set of written and unwritten norms that link with the ecological balance in the governance of the institutions as well as the organizations in the globe. It is in fact, intellectual governance on the environment for the sustainable development that includes the environmental systems, reducing environmental stresses, reducing human vulnerability etc.

\section{An Explanation of the Environmental Rights}

It is a very vast issue as mentioned earlier to understand the environmental rights. Some of its meanings are discussed below:

According to Cai:" The environmental rights as the basic rights and obligations enjoyed by the subjects of legal relationships in environment that they rely on and survive.

According to Lu Zhongmei: 'Environmental rights as the citizen's rights to survive and use resources in the unpolluted and not destroyed environment."

According to Chen: 'Environmental rights as the basic rights the subjects of environmental legal relationship enjoy the appropriate environment for healthy living and use the environment and resources rationally.

According to the Environmental Protection and Human Rights: Conceptual Aspects, J.G. Merrill's: the study abridges the major problems in the research on environmental rights from five aspects such as the definition of environmental rights, harmonious development with the nature and human beings, constitutional matters etc. The concept of anthropocentrism and the eco-centrism deal with the environmental rights. The human beings have been occupying the environment and its natural resources and do their own interests. Their activities are based on the anthropocentrism. Their activities may go against the nature and can cause numerous environmental problems that may threaten the survival of human beings. Some ecologists proposed the concept of eco-centrism.

\subsection{Elements of the Environmental Rights}

There are some important elements dealt in the Aarhus Convention along with many international environmental treaties. Some of the discussions are made here in this regard.

\subsubsection{The Right to Environmental Information}

Information is recognized as a prerequisite to effective national and international environmental management, protection and co-operation. It ensures all preventive or mitigating measures to be taken for the environment. It also ensures the participation of citizens in national decision making process and can influence consumer behaviour. It allows international community to determine the relations including in compliance with the legal obligations. It may be treated as one of the pillars of the environmental protection and development for achieving the sustainable development without which the development can not be made possible. The right to information to environment has discussed in many national international and regional laws

\subsubsection{Participation in the Decision Making Process}

Broad public participation is one of the fundamental prerequisites for the achievement of sustainable development. It has two elements such as the right to heard and the right to affect the decisions. All persons in accordance with the laws of the land/national legislation shall have the opportunity to participate in the decision making process relating to their environment involved and shall have access to means of redress when their environment has suffered damage or degradation. It includes and ensures the participation concerned all irrespective of race, language, sex, religion, color etc. Relevantly, some articles may be discussed here in this line: The Rio Declaration ensures in participating and encouraging the non-governmental organizations and the 
representative of Economic Interest. The Rio Declaration, principle 10 with Agenda 21 recognizes the need for public participation. The Agenda 21 also strongly emphasizes the importance of public participation. It encourages government to create policies that facilitate a direct exchange of information between the government and the public in environmental issues, suggesting the EIA process as a potential mechanism. It confirms the public opinions to support the conservation of the world's ecosystem.

\subsubsection{The Right to Remedy}

It is also discussed in the international human rights law and the international environmental laws as well. The European Convention on Human Rights Article 10 guarantees remedy whenever there is a violation of the rights and freedoms contained in the Convention. The Inter-American and African Regional Human Rights systems contain similar provisions. The Rio Declaration, Principle 10 provides that effective access to judicial and administrative proceedings, including redress shall be provided. The Agenda 21 provides the legal redress for affecting the environmental infringement under the law. The UNCLOS also proves that the State shall ensure the prompt and adequate compensation or other relief in respect of damage caused by pollution of the marine environment by natural or juridical persons under their jurisdiction [Ar. 235(2)].

\section{Other Relevant Considerations}

\subsection{Right to Harmonious Development with the Nature}

There is a close relationship between the nature and the human being. Human being is a part of nature and created naturally. It is said in the Quran that "human being is the best creation of all beings on the earth." This relation has gone through a cycle based on the concept of anthropocentrism and eco-centrism. The natural resources can only be rational utilizations and be judicious utilized. The natural beings cannot speak but feel the environment and its impacts.

\subsection{Some Information on the International Aspects}

Some important initiatives are made to explore the idea of the environmental rights which are discussed in the several background papers. The Stockholm Conference 1972, the Rio declaration, the World Charter etc., are notable. The conference on the Human Environment reads as to "inspire and guide the people of the world in the preservation and enhancement of the Human Environment." The delegation of the conference also affirmed that to "defend and improve the human environment for present and future generations has become an imperative goal for mankind". It was also agreed that "in order to achieve this environmental goal, it will demand the acceptance of responsibility by all citizens and by enterprise and institutions at every level, all sharing equitably in common efforts" It seems that the environmental goals stand for ensuring the rights to all beings on the earth. It does not need to explain more than that. It includes all participation including the civil society which is very important for the preservation and conservation of the environment peacefully. According to Eric Dannenmaier pointed that the conference did not explain the environmental rights due to its diversified discussion that represents the environmental rights. The World Charter of the United Nations focused almost the same kind. It called for all people to safeguard the natural environment. It also represents all to maintain the environmental ethics and justice regarding the environment.

\section{The Environmental Rights and the Human Rights}

The Environmental procedural rights are linked with the human rights. Environmental rights such as the access to information, right to healthy environment, public participation etc., are found in the international and national human rights laws. It not only depends on the attitude of the State but also the civil society. The environmental rights as mentioned in the international environmental laws may be justified in connection with the human rights perspective focusing the rights mentioned in the International Human Rights Legal Foundation such as the Magna Carta, 1215; the Petition of Rights, 1628 and the Bill of Rights, 1689; the Act of Settlement, 1701; the French Declaration of Rights of Man and of the Citizen, 1789, the Universal Declaration of Human Rights, 1948; the International Covenant on Civil and Political Rights, 1966; the International Covenant on Economic, Social and Cultural Rights, 1966; the International Convention on the Elimination of All Forms of Racial Discrimination, 1966; only for bringing about the sustainable development and environment. The close links are found in the articles mentioned of the treaties such as The Framework Convention on Climate Change (Art. 4(1)(i); The Biodiversity Convention (Arts 13, 17), The Framework Convention on Climate Change, The Helsinki Convention on the Protection and Use of Tran boundary Watercourses and International Lakes (Art. 16); The Espoo Convention on Environmental Impact Assessment in a Tran boundary Context ((Art. 3(8)); The Paris Convention on the North East Atlantic (Art. 9).The Regional Human Rights Laws are also dealing with the environmental rights such as the European Convention on Human Rights art. 10 guarantees that the freedom to 
receive information in general. It is also observed that the rights relating to the environmental rights in relation to human rights are also found in the aims, objectives with mission and vision of the Regional Organizations and their laws. Within the European Community, the right to information generally means that the individual has the right to be informed about the environmental compatibility of products, manufacturing processes and their effects on the environment, and industrial installations. Specific directives vary in regard to public rights to information while others provide that information shall be available to the public concerned in accordance with legal procedures. The Stockholm Declaration, Principle 1 reads as "Man has the fundamental right to freedom, equality and adequate conditions of life, in an environment of a quality that permits a life of dignity and well being, and he bears a solemn responsibility to protect and improve the environment for present and future generations." It links human rights as a fundamental goal and environmental protection as an essential means to achieve the adequate conditions for a life of dignity and well being that are guaranteed.

\section{Human Rights and Fundamental Rights}

It is noted that after 1948, most of the new States of the world accepted the human rights as their fundamental rights as enumerated in the Universal Declaration of Human Rights 1948. The fundamental rights are treated as the part of the human rights. Therefore, a close relation is prevailing between these two rights and ultimately, these two rights driving force of the environmental rights. The table 4 also examines these rights.

\section{Some Constitutional Spirits}

We may start with the following statement: "All peoples shall have the right to a general satisfactory environment favourable to their development."-African Charter on Human and Peoples Rights, Art. 24. The constitutions of more than seventy countries adopted or revised since 1970, either state the principle that an environment of a specified quality constitutes a human right or impose environmental duties upon the state. Art. 50 of the Constitution of the Ukraine, adopted 28 June 1996 is an example. It states that "every person has the right to a safe and healthy environment and to compensation for damage resulting from the violation of this right.' The other constitutions such as the Hungary, South Africa, Nicaragua, Korea, turkey refer to a decent, healthy environment. The Korean Constitution refers to a pleasant environment. The Peru, Philippines; Portugal refers to natural, clean, ecologically balanced environment. The Chile refers to safe environment or one free from contamination environment.

\section{The Environmental Rights and the Principles of the International Environmental Laws}

There are principles underlined in the international environmental laws under the public international law which is very essential to the protection and sustainable development and environment of the globe. It should be truly understood. The principles of the International Environmental Laws are found in the relevant website.

\section{Some Judicial Responses}

Some landmark judicial judgements are made in the subcontinent including Bangladesh and India to protect the environmental rights in the form of public Interest Litigation. The list of case laws is attached in the appendix in this regard. Also some other judgements are also made in the other parts of the world to protect the interest of the society which has been made due to the pollution of the society as mentioned the causes earlier. The European Court plays an important role based on the article 10 of the European Convention on Human Rights. The case laws may be found in the Bangladesh Environmental Lawyers Association, (BELA) Website.

\section{The Role of Civil Society}

It is observed that the aims and objectives of the civil society including the non Governmental Organizations, trade unions, manufacturers, individual members of the community etc., bear relevancy with the environmental development and conservation. Most of the cases, this society deals and likes to work with the human rights, environmental development, humanity, child rights, human culture and heritage etc. Their efforts and importance are recognized at home and abroad by the legislations. The significance of the NGOs is reflected in the emphasis on their role in recent treaties such as the Desertification Convention, which speaks in it's preamble of "the special role of non-governmental organizations and other major groups in programs to combat desertification and mitigate the effects of drought." The Brund land Commission recommended that government establish official consultation with NGOs to share information, strategies and resources, and permit meaningful participation in all aspects of environmental matters. NGOs representatives played a major role before and during the Rio Conference.

\section{Report on the Case Study}

The Government of Malaysia passed several environmental laws and policies to protect the environment of Malaysia. But unfortunately, these laws are not implemented effectively due to several causes as mentioned in 
the abstract. It is concerned that there is no Environmental Courts in Malaysia which is quite unhealthy to the people of Malaysia. It needs to reform in the policy level in order to ensure environmental rights to all. The Government also approved some international initiatives which are really relevant but it regrets that the necessary measures such as the Information Act along with our recommendations in the international environmental laws are not properly implemented. A case study was done as mentioned in the abstract highlighting the indicators as follows:

\section{Some Key Indicators:}

ERM=Environmental Remarks

$\mathrm{ER}=$ Environmental Rights

HR=Human Rights

$\mathrm{TR}=$ Total Respondents

- Clean and Healthy Environment in Malaysia

- $\quad$ Clean and Healthy Environment (60-100) \%=Good;

- $\quad$ Partial Clean and Healthy Environment (50-60) \%=Fair;

- $\quad$ Not Clean and Healthy Environment (30-50) \%= Unexpected;

- Idea on Environmental Rights and Human Rights? a) Yes, b) No

- Relationship between the Environmental Rights and Human Rights? a) Yes, b) No.

Table 1 . The statistics of clean and healthy environment

\begin{tabular}{lllllll}
\hline SL & Indicators (30\%-100\%) & TR & $\mathbf{( 6 0 \% - 1 0 0 \% )}$ & $\mathbf{( 5 0 \% - 6 0 \% )}$ & $\mathbf{( 3 0 \% - 5 0 \% )}$ & ERM \\
\hline 1. & Clean and Healthy Environment & 50 & 10 & 25 & 15 & Fair \\
& & & $(20 \%)$ & $(50 \%)$ & $(30 \%)$ & \\
\hline
\end{tabular}

Table 2. The statistics of any idea on ER \& HR

\begin{tabular}{llllll}
\hline SL & Indicators & TR & Yes & No & ERM \\
\hline 1. & Any idea on ER \& HR & 50 & 20 & 30 & Fair \\
& & & $(40 \%)$ & $(60 \%)$ & \\
\hline
\end{tabular}

Table 3. The statistics of any relationships between ER \& HR

\begin{tabular}{llllll}
\hline SL & Indicators & TR & Yes & No & ERM \\
\hline 1. & Any relationships between ER \&HR & 50 & 45 & 5 & Good \\
& & & $(90 \%)$ & $(10 \%)$ & \\
\hline
\end{tabular}

The Table 1 indicates that the 50\% people think that they are enjoying the partial clean and healthy environment in Malaysia. The only $20 \%$ people think that they have clean and healthy environment. The rest of $30 \%$ people think that they don't have any clean and healthy environment in Malaysia. The Table 2 shows that the $40 \%$ people have some any ideas on the Environmental Rights and the Human Rights and the rest of the $60 \%$ people don't have any idea in this regard. The Table 3 indicates that the $90 \%$ people think that there is a relationship between the Environmental Rights and the Human Rights and the rest of the 10\% don't think so. The Tab 4: An Interface with the Human Rights, Environmental Rights and Fundamental Rights or the Constitutional Rights is showed here: ER=Environmental Rights recognized by the International Environmental Law and Courts; HR= Human Rights recognized by the Universal Declaration of human Rights 1948; FR/CR= Fundamental Rights/Constitutional Rights recognized by the Constitutions $\mathrm{CR}=$ Category of Rights. 
Table 4. List of rights

\begin{tabular}{lll}
\hline SL & CR & \\
\hline 1. & $E R$ & $\begin{array}{l}\text { Basic Rights (Food, Clothing, Housing, Medical, Life, Association, Expression, Liberty, Equality, Health Decent Living, decent } \\
\text { working Environment, Safe Environment, Healthy Environment, Harmony with the, Access to Justice, Standard of Life Solidarity } \\
\text { etc }\end{array}$ \\
\hline 2. & $H R$ & $\begin{array}{l}\text { Equal in dignity and rights, freedom of movement, right to life, liberty and security of person, inhuman or degrading treatment or } \\
\text { punishment, equal protection, no arbitrary arrest, detention or exile, freedom of thought, conscience and religion, freedom of } \\
\text { opinion and expression freedom of peaceful assembly and association, Education, cultural life etc. }\end{array}$ \\
\hline 3. & $F R$ & $\begin{array}{l}\text { Equality, protection of law, life and personal liberty, Freedom of movement, Freedom of association, Freedom of thought and } \\
\text { conscience and of speech, Freedom of profession or occupation, Protection of home and correspondence } \\
\text { Free and compulsory education etc. }\end{array}$ \\
\hline
\end{tabular}

\section{Recommendations}

Some recommendations may be made in the following two ways:

\subsection{Field Based Recommendations}

The following Recommendations are made based on the case studies:

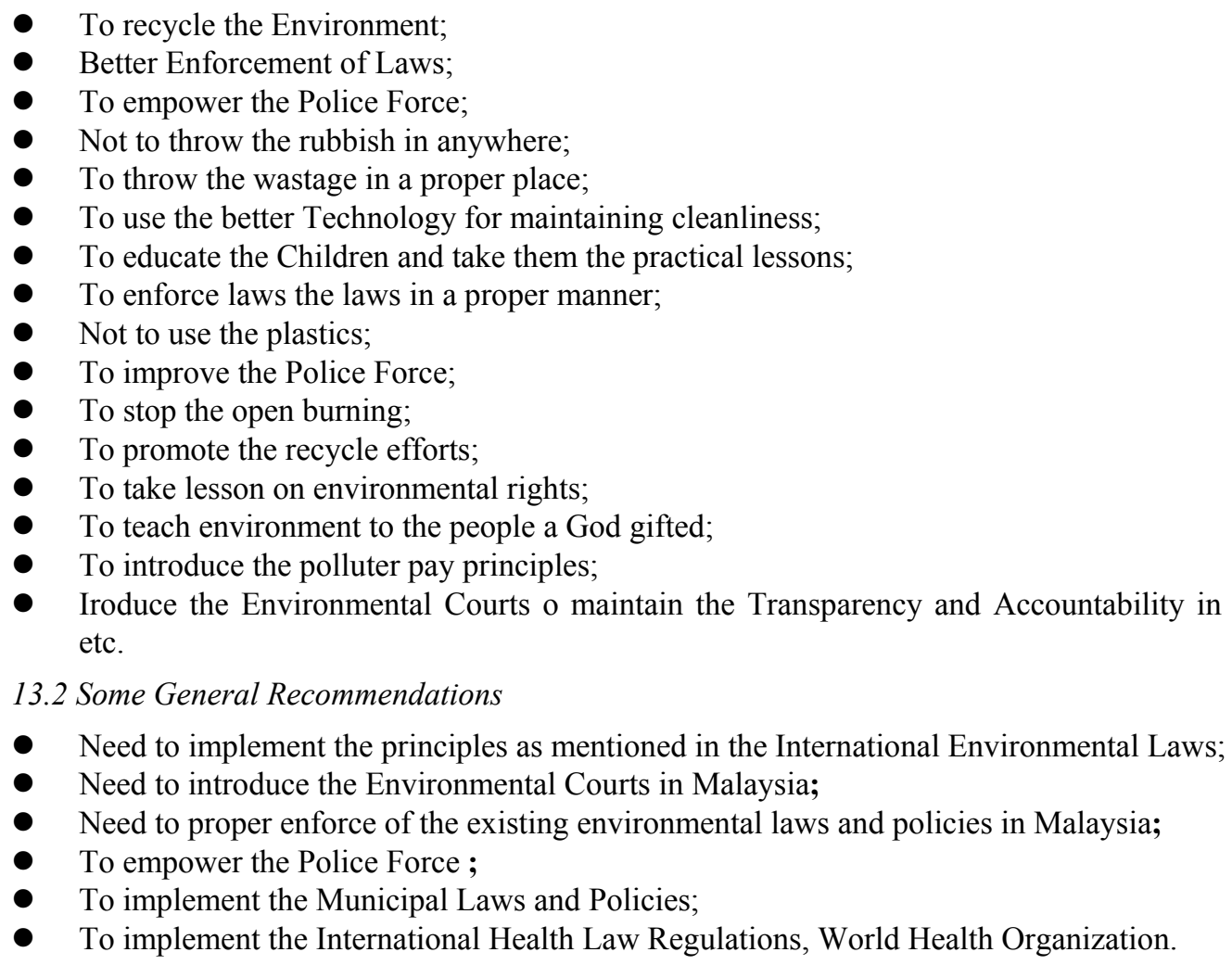

\section{Conclusion}

From the above the study, it may be said that there are many laws on the environmental rights and policies but hardly realized these rights. The existing laws and policies are not properly implemented due to many causes such as lack of co-ordination, lack of enforcement of the laws and policies etc. The above case study finds the partial clean environment is prevailing in Malaysia. This situation needs to be improved by taking appropriate measures as mentioned in the abstract. Our practice is that we have enough law but the implementation is hardly observed. We need to implement the existing international environmental laws including the Human Rights with the recommendations. In addition, the existing research findings on the international environmental laws related to environmental rights needs to be implemented for our clean and healthy environment thinking own existence and sake of our planet, the home. 


\section{Acknowledgements}

The author would like to express his sincere gratitude to those who has helped him directly or indirectly to complete this paper and would like to acknowledge to the 2010 International Conference on Humanities, Historical and Social Sciences(CHHSS 2010), Singapore, 26-28 February, 2010 as well for publishing my proceedings.

\section{References}

Ann, D. (2004). Friends of the Earth International, Our Environment, Our Rights standing up for people and the Planet. Amsterdam: Friends of the Earth International.

Chen, D., \& Dong, Z. G. (2009). Environmental Rights: On the Perspective of Harmonious Development between Human Beings and Nature. China Population, Resources and Environment, 18(1).

Dinah, S. (nd). The list of the International Environmental Treaties. Retrieved from http://193.194.138.190/environment/bp4.html

Klaus, B., Ron, E., \& Pure, T. (2008). Governance for Sustainability Issues, Challenges, Success. Gland: IUCN, Gland, Switzerland in Collaboration with the IUCN Environmental Law Centre, Bonn, Germany.

Robert, T. W., \& Barbara, Y. (2008). Environment on the Edge. International Assessment of Agricultural Science and Technology for Development, 51.

Singh, S. N. (1997). Environmental Psychology. India: Pointer Publishers.

\section{Copyrights}

Copyright for this article is retained by the author(s), with first publication rights granted to the journal.

This is an open-access article distributed under the terms and conditions of the Creative Commons Attribution license (http://creativecommons.org/licenses/by/3.0/). 